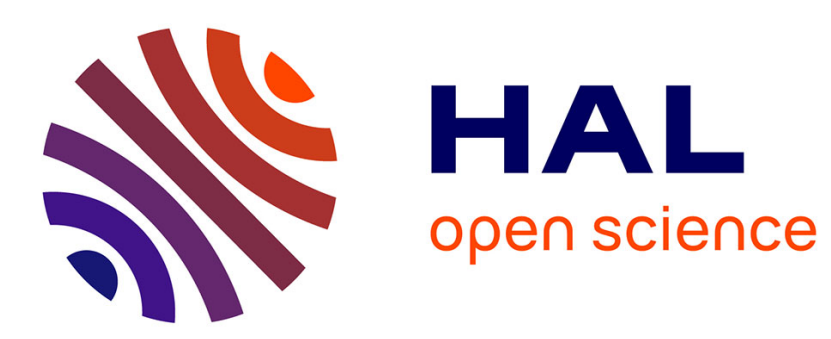

\title{
Species assemblages and diets of Collembola in the organic matter accumulated over an old tar deposit
}

Servane Gillet, Jean-François Ponge

\section{To cite this version:}

Servane Gillet, Jean-François Ponge. Species assemblages and diets of Collembola in the organic matter accumulated over an old tar deposit. European Journal of Soil Biology, 2005, 41 (1-2), pp.3944. 10.1016/j.ejsobi.2005.07.001 . hal-00496566

\section{HAL Id: hal-00496566 https://hal.science/hal-00496566}

Submitted on 30 Jun 2010

HAL is a multi-disciplinary open access archive for the deposit and dissemination of scientific research documents, whether they are published or not. The documents may come from teaching and research institutions in France or abroad, or from public or private research centers.
L'archive ouverte pluridisciplinaire HAL, est destinée au dépôt et à la diffusion de documents scientifiques de niveau recherche, publiés ou non, émanant des établissements d'enseignement et de recherche français ou étrangers, des laboratoires publics ou privés. 
1 Species assemblages and diets of Collembola in the organic matter accumulated

14 Abstract An oil refinery was abandoned in 1964 at Merkwiller-Pechelbronn (Alsace, 15 France). We investigated the food diets and species assemblages of Collembolan

\section{over an old tar deposit}

\author{
Servane Gillet, Jean-François Ponge*
}

Museum National d'Histoire Naturelle, CNRS UMR 5176, 4 avenue du Petit Château, 91800 Brunoy, France

* Corresponding author. Fax: +33-1-60465009.

E-mail address: jean-francois.ponge@wanadoo.fr

Running title: Collembola over tar communities living in a thick pasty tar deposit overlaid by an organic soil, by comparison with an adjacent unpolluted plot. At the polluted plot the species richness of the springtail community was low (9 species, versus 27 at the unpolluted plot) but its total abundance was at the same level in both plots. Most springtails consumed more fungi than bacteria at the polluted plot, contrary to the unpolluted plot. Changes in habitat features and food resources might explain the observed decrease in local biodiversity, rather than direct PAH toxicity.

Keywords: Collembolan communities; Gut contents; Polycyclic Aromatic Hydrocarbons

\section{Introduction}


1 The direct toxicity of pollutants to soil animals has been widely reported and

2 indirect effects, for instance through changes in habitat and food quality, are probable $3[3,11]$.

Polycyclic Aromatic Hydrocarbons (PAHs), such as naphthalene, phenanthrene, 6 or benzo[a]pyrene, are toxic aromatic compounds [2,24] which are nonpolar, 7 hydrophobic and neutral molecules composed of two or more fused benzene rings in 8 linear, step, or cluster arrangement. Nowadays, their presence in the soil results mainly 9 from industrial activities such as coke production, petroleum refining and other hightemperature industrial processes, which induce pollution by accidental oil spilling and waste deposition, even long after site abandonment. Field studies revealed that the presence of PAHs decreases the biodiversity of soil animal communities and changes their vertical distribution $[1,10]$. Laboratory bio-assays have demonstrated toxic and anaesthetic effects of PAHs on soil animals [7,5,8], as well as bioaccumulation [17] and avoidance [18].

Our study site was a petroleum refinery abandoned in 1964. It still displays a patchy pollution of soil and ponds by PAHs. The aim of our work was to study the impact of this type of pollution on soil fauna by a comparison between a plot polluted by

20 PAHs and a nearby unpolluted control plot. In a parallel study on the composition of humus profiles, we observed that the organic matter which accumulated over the 40 year-old tar deposits was permeated by a large population of mycorrhizal fungi, in contrast to the adjacent unpolluted plot which was characterized by the rapid incorporation of litter to mineral matter through earthworm activity [12]. We used a community-level approach to evaluate the impact of PAHs on the saprophagous compartment of the ecosystem. The collembolan community (Arthropoda: Hexapoda) was chosen for its great abundance and diversity in a wide variety of soil types $[19,20]$ and the flexibility of its alimentary habits $[11,15,21]$. Population indices and food bolus 
1 analyses were used to follow changes in function and biodiversity of collembolan

2 populations under the influence of $\mathrm{PAH}$ pollution.

4 2. Materials and methods

5

6 2.1. Study site

7

The study was conducted at the site of the petroleum refinery of Merkwiller-

9 Pechelbronn, about $50 \mathrm{~km}$ north of Strasbourg (Alsace, France). The refinery had an

10 intensive activity until 1964, afterwards it was progressively dismantled then totally

11 abandoned. The site is located on the Merkwiller-Pechelbronn oil field (bituminous

12 sand) on the western edge of the Rhine rift valley. The superficial soil $(5 \mathrm{~m})$ is

13 composed of recent fluvial deposits overlaying $1400 \mathrm{~m}$ thick sediments above the

14 granitic substratum [26].

Nowadays, the site area (20 ha) is characterised by the presence of old buildings now included in a great variety of naturally established ecosystems (woodland, grassland, ponds) with zones polluted by hydrocarbons, in particular by tar deposits. Two plots (polluted versus unpolluted used as control), were sampled in

20 October 2002. They were considered to be representative of the patchy occurrence of 21 tar, as ascertained by the examination of a number of adjacent (polluted and unpolluted) soil profiles. The polluted plot, approximately $20 \mathrm{~m}^{2}$, was characterised by 23 a thick pasty tar patch overlaid by a 3-5 cm organic layer, a discontinuous field layer composed of Hedera helix, Geranium robertianum, Carex pilosa, Solidago canadensis and Taraxacum officinale, a shrub layer composed of Fraxinus excelsior, Rubus

26 fruticosus and Salix capraea and a tree layer composed of Acer campestre, Betula

27 pendula and Quercus robur. The unpolluted, control plot was located $15 \mathrm{~m}$ south of 28 the polluted plot, and its surface was arbitrarily fixed to $20 \mathrm{~m}^{2}$, for the sake of 
1 comparison, although it did not differ from the rest of the site. It was characterised by a

2 much greater plant biodiversity and a good earthworm mull humus. The field layer was

3 composed of Hedera helix, Arum maculatum, Carex pilosa, Fragaria vesca, Geranium

4 robertianum, Geum urbanum, Potentilla reptans, Stachys sylvatica, Solidago

5 canadensis and Taraxacum officinale, the shrub layer was composed of Acer

6 pseudoplatanus, Carpinus betulus, Cornus mas, Cornus sanguinea, Crataegus

7 monogyna, Fraxinus excelsior, Ligustrum vulgare, Prunus avium, Rosa canina and

8 Rubus fruticosus, and the tree layer was composed of Acer campestre, Prunus avium

9 and Quercus robur.

11 2.2. Sampling and identification of animals

Collembola were sampled on the organic matter accumulated over the tar

14 deposit and in the adjacent unpolluted plot. At each plot, five soil cores, $5 \mathrm{~cm}$ diameter

15 and $10 \mathrm{~cm}$ depth (litter included), were collected with a core sampler and, after

16 discarding tar pieces, stored in plastic bags. Springtails were extracted from soil/litter

17 by the dry-funnel method [9] and preserved in 95\% (v/v) ethyl alcohol until sorting and

18 identification. The animals were sorted under a dissecting microscope, then mounted in

19 chloral-lactophenol ( $25 \mathrm{ml}$ lactic acid, $50 \mathrm{~g}$ chloral hydrate, $25 \mathrm{ml}$ phenol). They were

20 identified to species level using a phase contrast microscope at 500x and several keys

21 and diagnoses $[4,6,13,16,23,27,28,29]$. We calculated in each sample the total

22 abundance, the the species richness, the Shannon Index and the equitability. We also

23 calculated the total species richness of the five samples taken at each plot.

\subsection{Observation of gut contents}


Gut contents from each mounted Collembola were observed under phase

2 contrast at 500x magnification and classified in twelve categories:

3

4

- Melanized hyphae

5

- Hyaline hyphae

6

- Fungal spores

7

- Bacteria

- Mineral particles

- Holorganic humus (amorphous organic matter)

- Hemorganic humus (mixture of organic matter and mineral particles)

- Micro-algae

- Pollen grains

- Empty guts

15 The proportion in volume of the different categories was visually estimated to the next $165 \%$ in each animal gut then averaged by species and by site.

\subsection{Chemical analyses}

Samples were collected in April 2003 to determine the amount of PAHs from the

21 EPA list [14] in (1) the 10 top $\mathrm{cm}$ of the A horizon of the control soil (2) the tar deposit 22 at $10-20 \mathrm{~cm}$ depth and (3) the OF horizon overlying the tar deposit. To check the 23 validity of our control plot, samples were collected in May 2003 in the park of the 24 laboratory (Brunoy, lle-de-France, France), in the 10 top $\mathrm{cm}$ of a similar soil (rich earthworm mull at neutral $\mathrm{pH}$ ) under deciduous woody vegetation. Composite samples

26 were taken from each plot, then kept in glass jars and rapidly transported to the

27 laboratory. Then, soil samples were homogenised and sieved at $1 \mathrm{~cm}$ then kept in 
1 glass jars at $-18 \mathrm{C}^{\circ}$ until analysis. Each sample was defrozen, dried, then sieved at 2 $2 \mathrm{~mm}$.

PAHs were extracted from each sample with the automatic system ASE 200

5 (Accelerated Solvent Extraction) DIONEX, using a mixture of dichloromethane and 6 acetone (50/50) for soil and acetonitrile for tar. The extract was concentrated under

7 forced air with a TuroVap LV (Zymark), then PAHs were separated by HPLC (High 8 Power Liquid Chromatography) with UV detection (alliance 2690 chain, PDA 996 9 detector, column LC-PAH Supelco). After sieving the contaminated soil, which was 10 mainly made of badly decomposed tree litter, only a small amount of fine matter was 11 available for analysis, and only 7 major PAHs could be analysed on this material: 12 naphthalene, phenanthrene, fluoranthrene, pyrene, benzo(a)anthracene, chrysene and 13 benzo(ghi)perylene, the others being under detection level $(0.02 \mu \mathrm{g} / \mathrm{g}$ for 14 uncontaminated soil, $0.04 \mu \mathrm{g} / \mathrm{g}$ for contaminated soil, $0.1 \mu \mathrm{g} / \mathrm{g}$ for tar). All 15 measurements were done in triplicate.

After extraction of fauna, air-dried soil was stored in plastic bags for $\mathrm{pH}$ measurement. The soil was suspended in deionized $\mathrm{H}_{2} \mathrm{O}$ and $1 \mathrm{M} \mathrm{KCl}$ (1:5 soil:water v:v) for $\mathrm{pH} \mathrm{H}_{2} \mathrm{O}$ and $\mathrm{pH} \mathrm{KCl}$, respectively. Each suspension was shaken for five

20 minutes, then $\mathrm{pH}$ was measured in the supernatant after sedimentation for $2 \mathrm{~h}$ with a 21 glass electrode. The difference between these two measurements $(\delta \mathrm{pH})$ was taken as 22 an estimate of exchange acidity.

\subsection{Statistical treatment}

Non-parametric Mann-Whitney tests were performed to compare chemical parameters $(\mathrm{pH})$ and population parameters (abundance, species richness, diversity 
1 and equitability of collembolan communities) between sites, using samples as

2 replicates (five in each site).

\section{Results}

5

$6 \quad$ 3.1. Chemical analyses

7

The distribution of the 16 PAHs of the EPA list and the total amount of PAHs were quite similar in the control soil from the Merkwiller-Pechelbronn site and in the soil from the park of the laboratory (Table 1). As a consequence we estimated that the plot chosen as a control at Merkwiller-Pechelbronn was valid. The total amount of the seven PAHs analysed in the soil over the tar deposit at Merkwiller-Pechelbronn (5.95 $\mu \mathrm{g} / \mathrm{g})$ was six times higher than the corresponding amount at the control plot $(0.93$

$14 \mu \mathrm{g} / \mathrm{g}$ ). The concentration of benzo(ghi)perylene was eleven times higher than the control, while the amount of fluoranthrene was only three times higher.

The $\mathrm{pH}$ measured in water and potassium chloride was neutral and did not differ between both sites at Merkwiller-Pechelbronn (Table 1). However, mann-Whitney $\mathrm{U}$ test revealed that exchange acidity, expressed by $\delta \mathrm{pH}$, was higher on the unpolluted site.

\subsection{Collembolan communities}

At the unpolluted plot 27 species were found whereas only 9 were found in the polluted zone. The species richness per sample, the Shannon Index and the

26 equitability were higher at the control than at the contaminated plot (Table 2). However,

27 the total abundance of springtails did not differ between plots. 
Only five species were common to both polluted and unpolluted plots: Folsomia

3 candida, Parisotoma notabilis, Sminthurides malmgreni, Sminthurides parvulus and

4 Sminthurinus aureus. Among these species, S. aureus was significantly more abundant

5 in the control soil ( $x$ 4). Over the tar deposit, $83 \%$ of the total abundance was

6 represented by Proisotoma minuta (43\%) and Parisotoma notabilis (40\%). P. minuta

7 was present in all samples taken at the polluted plot while it was absent from all

8 samples taken at the control plot. The abundance of this species (together with that of

9 Paristoma notabilis in most samples from the tar deposit) explains why the total

10 abundance of Collembola did not differ between plots in spite of a much lower number

11 of species at the polluted plot (Table 2).

\subsection{Diets of Collembola}

The food diet of the three species Parisotoma notabilis, Folsomia candida and

Sminthurinus aureus was compared between plots (Figure 1). Fungal mycelium was more common at the polluted plot, while the contrary was observed for bacteria, except in $F$. candida guts which showed bacteria in equal proportion in both sites but more hyaline hyphae and hemorganic humus over the tar deposit. The proportion of empty

20 guts was higher at the polluted plot for $P$. notabilis and $S$. aureus.

The diet of $S$. aureus was more diverse at the unpolluted plot, containing microalgae, pollen, humus, bacteria and fungal spores and mycelia, but only fungal mycelium in the polluted plot. However the latter observation could be an artifact due to the low number of specimens (3) collected over the tar deposit. The gut of the

26 bacteriophagous species $M$. minimus contained $68 \%$ bacteria, and this species was

27 only present at the unpolluted site, where it was found in all samples. The isotomid $P$. 
1 minuta, which was present only at the polluted site where it dominated the community,

2 showed a high proportion of empty guts (67\%), $21 \%$ mycelium and few bacteria ( $2 \%)$.

\section{Discussion}

In spite of a slight distance between plots and a low concentration of PAHs over

7 the tar deposit (Table 1), a great dissimilarity in collembolan communities was observed between the organic soil accumulated over the tar deposit and the adjacent control soil (Table 2). It should be noticed that sieving of the soil to $2 \mathrm{~mm}$ before PAH extraction (see Materials and methods) could have led to underestimate PAH concentration in the soil over tar. The toxicity of crude oil for Collembola was shown by Sendstad [25] who found $2 \%$ of total Collembola in a polluted plot compared to a control plot. Three years after application, toxicity was still present given the absence of recolonisation by fauna of the polluted zone. In our study, the collembolan community could be affected by i) the presence of pollutants in the soil, through direct effects of PAHs or other toxic compounds on the most sensitive species and/or ii) indirect effects such as changes in food resources. Like in a previous study on a site polluted by heavy metals [11], the species richness of springtail communities was observed to decrease under the influence of pollution, at constant or even higher total abundance. In both cases, this could be explained by an increase in free habitats liberated by most sensitive species. Isotomids seemed to be less sensitive to PAH pollution, as was also observed by Blakely et al. [3]. Here this group was represented by the two dominant species Proisotoma minuta and Parisotoma notabilis.

In our study, changes were observed in the diet of springtails under the influence of pollution by hydrocarbons. This shift can be explained by a change in the

27 use of food resources, since fungi were favoured to the detriment of bacteria. This possibility reflected a change in the composition of microbial communities in the favour 
1 of fungi, which could explain why the bacteriophagous Megalothorax minimus was only

2 present at the unpolluted plot. Micromorphological analyses showed a high amount of

3 ectomycorrizal fungal hyphae in the organic matter accumulated over the tar deposit

4 with a poor earthworm activity, while a rapid incorporation of organic matter to mineral

5 matter through earthworm activity was registered in the control soil [12]. Shifts in

6 microbial communities in favour of fungi could be better explained by a change in

7 humus form (and associated foodwebs) than by the direct toxicity of PAHs to

8 microorganisms [3].

We found strong changes in invertebrate communities and alimentary habits of soil animals forty years after abandonment of industrial activity. Despite a low PAH concentration in the soil accumulated over the tar deposit (Table 1), the inability of earthworm populations to colonize pollution spots, and the development of a superficial ecto-mycorrhizal root mat caused significant changes in the environment of animal as well as microbial communities. Given the shift from mull (dominated by earthworm activity) to moder (dominated by enchytraeid activity) ascertained by micromorphological analysis [12], the observed decrease in biodiversity and change in the food diet of the Collembolan community can be ascribed, at least partly, to a change in humus form [22].

\section{Acknowledgements}

We thank the Agence de l'Environnement et de la Maîtrise de l'Energie (ADEME) for financial support and Vasilica HAMMADE and Laurence BELKESSAM from the Centre National de Recherches sur les Sites et Sols Pollués (CNRSSP, Douai, France) for $\mathrm{PAH}$ analyses. 
2 [1] G.R. Best, J.V. Nabholz, J. Ojasti, D.A. Crossley Jr, Response of microarthropod populations to naphthalene in three contrasting habitats, Pedobiologia 18 (1978) 189-201.

5

6 [2] A. Bispo, M.J. Jourdain, M. Jauzein, Toxicity and genotoxicity of industrial soils polluted by polycyclic aromatic hydrocarbons (PAHs), Org. Geochem. 30 (1999) 947-952.

[3] J.K. Blakely, D.A. Neher, A.L. Spongberg, Soil invertebrate and microbial communities and decomposition as indicators of polycyclic aromatic hydrocarbon contamination, Appl. Soil Ecol. 21 (2002) 71-88.

[4] G. Bretfeld, Synopses on Palaearctic Collembola. II. Symphypleona, Abh. Ber. Naturkundemuseums Görlitz 71 (1999) 1-318.

[5] P. Chenon, A. Rousset, Y. Crouau, Genetic polymorphism in nine clones of a parthenogenetic collembolan used in ecotoxicological testing, Appl. Soil Ecol. 14 (2000) 103-110.

[6] K. Christiansen, M.M. Da Gama, P. Bellinger, A catalogue of the species of the genus Pseudosinella, Ciência Biol 5 (1983) 13-31.

[7] Y. Crouau, P. Chenon, C. Gisclard, The use of Folsomia candida (Collembola, Isotomidae) for the bioassay of xenobiotic substances and soil pollutants, Appl. Soil Ecol. 12 (1999) 103-111. 
1 [8] P.B. Dorn, T.E. Vipond, J.P. Salanitro, H.L. Wisniewski, Assessment of the acute toxicity of crude oils in soils using earthworms, Microtox®, and plants, Chemosphere 37 (1998) 845-860.

4

5 [9] C.A. Edwards, K.E. Fletcher, A comparison of extraction methods for terrestrial arthropods. In: J. Phillipson (Ed), Methods of Study in Quantitative Soil Ecology: Population, Production and Energy Flow. Blackwell, Oxford, UK, 1971, pp. 150185.

[10] K.M. Erstfeld, J. Snow-Ashbrook, Effects of chronic low-level PAH concentration on soil invertebrate communities, Chemosphere 39 (1999) 2117-2139.

[11] S. Gillet, J.F. Ponge, Changes in species assemblages and diets of Collembola along a gradient of metal pollution, Appl. Soil Ecol. 22 (2003) 127-138.

[12] S. Gillet, J.F. Ponge, An optical analysis of the organic soil over an old petroleum tar deposit (submitted).

[13] H. Gisin, Collembolenfauna Europas, Muséum d'Histoire Naturelle, Geneva, Switzerland, 1960.

[14] J.C. Greene, C.L. Bartels, W.J. Warren-Hicks, B.R. Parkhurst, G.L. Linder, S.A. Peterson, W.E. Miller, Protocols for Short-Term Toxicity Screening of Hazardous Waste Sites, EPA/600/3-88/029, United States Environmental Protection Agency, Corvallis, Oregon, 1989. 
1 [15] M. Hasegawa, H. Takeda, Changes in feeding attributes of four collembolan populations during the decomposition process of pine needles, Pedobiologia 39 (1995) 155-169.

4

[16] S.P. Hopkin, A Key to the Springtails of Britain and Ireland, AIDGAP Test Version, The Field Studies Council Publications, Shrewsbury, UK, 2000.

[17] D.L. Johnson, K.C. Jones, C.J. Langdon, T.G. Piearce, K.T. Semple, Temporal changes in earthworm availability and extractability of polycyclic aromatic hydrocarbons in soil, Soil Biol. Biochem. 34 (2002) 1363-1370.

[18] M. Michelozzi, A. Raschi, R. Tognetti, L. Tosi, Eco-ethological analysis of the interaction between isoprene and the behaviour of Collembola, Pedobiologia 41

[19] H. Petersen, A review of collembolan ecology in ecosystem context, Acta Zool. Fenn. 195 (1994) 111-118.

[20] J.F. Ponge, Biocenoses of Collembola in atlantic temperate grass-woodland

[21] J.F. Ponge, Vertical distribution of Collembola (Hexapoda) and their food resources in organic horizons of beech forests, Biol. Fertil. Soils 32 (2000) 508522.

[22] J.F. Ponge, Humus forms in terrestrial ecosystems: a framework to biodiversity, Soil Biol. Biochem. 35 (2003) 935-945. 
1 [23] M. Potapov, Synopses on Palaearctic Collembola. III. Isotomidae, Abh. Ber. Naturkundemuseums Görlitz 73 (2001) 1-603.

4 [24] K. Schirmer, D.G. Dixon, B.M. Greenberg, N.C. Bols, Ability of 16 priority PAHs to be directly cytotoxic to a cell line from the rainbow trout gill, Toxicology 127 (1998) 129-141.

[25] E. Sendstad, Accelerated biodegradation of crude oil on arctic shorelines, In: Proceedings of the Third Arctic Marine Oil Spill Program Technical Seminar, Environment Canada, Ottawa, Canada, 1980, pp. 402-416.

[26] C. Sittler, Les hydrocarbures d'Alsace dans le contexte historique et géodynamique du fossé Rhénan, Bull. Centres Recherche Exploitation Production ELF-AQUITAINE 9 (1985) 335-371.

[27] J. Stach, The Apterygotan Fauna of Poland in Relation to the World-Fauna of this Group of Insects. Tribe: Orchesellini, Polish Academy of Sciences, Krakow, Poland, 1960.

[28] J. Stach, The Apterygotan Fauna of Poland in Relation to the World-Fauna of this Group of Insects. Tribe : Entomobryini. Polish Academy of Sciences, Krakow, Poland, 1963.

[29] B. Zimdars, W. Dunger, Synopses on Palaearctic Collembola. Part I. Tullbergiinae. Abh. Ber. Naturkundemuseums Görlitz 68 (1994) 1-71. 


\section{$1 \quad$ Figure legends}

2

3 Fig 1. Composition of the food bolus of Parisotoma notabilis, Folsomia candida, Sminthurinus aureus, Megalothorax minimus and Proisotoma minuta in the soil over tar (T) and the control soil (C) from Merkwiller-Pechelbronn site. The percentage contribution of each species to the total population is indicated between brackets 
Table 1

Chemical features of tar, organic matter accumulated over tar, control soil from Pechelbronn site and laboratory soil. Concentration of PAH (Polycyclic Aromatic Hydrocarbons) is expressed in $\mu \mathrm{g} / \mathrm{g}$ dry soil. Means of three replicated measures on pooled samples (PAHs) or of five replicate samples ( $\mathrm{pHs}$ ) are follow ed by standard errors. Significant differences among groups at 0.05 level (for $\mathrm{pH}$ only) are indicated by different superscript letters (Mann-Whitney test). d.I. = detection limit

\begin{tabular}{|c|c|c|c|c|}
\hline & Tar & Soil over tar & Control soil & $\begin{array}{c}\text { Laboratory } \\
\text { soil }\end{array}$ \\
\hline $\mathrm{pH}$ (w ater) & & $6.7 \pm 0.3$ & $7 \pm 0.4$ & \\
\hline $\mathrm{pH}$ (potassium chloride) & & $6.3 \pm 0.3$ & $6.2 \pm 0.4$ & \\
\hline$\delta \mathrm{pH}$ & & $0.4 \pm 0.04$ & $0.8 \pm 0.05$ & \\
\hline Naphthalene & $52.7 \pm 1.0$ & $0.493 \pm 0.022$ & $0.096 \pm 0.003$ & $0.064 \pm 0.005$ \\
\hline Acenaphthylene & $<$ d.l. & $<$ d.I. & $<$ d.l. & $<$ d.I. \\
\hline Acenaphthene & $<$ d.I. & $<$ d.l. & $0.038 \pm 0.002$ & $0.023 \pm 0.000$ \\
\hline Fluorene & $<$ d.I. & $<$ d.I. & $<$ d.l. & $<$ d.I. \\
\hline Phenanthrene & $151.1 \pm 2.8$ & $0.776 \pm 0.048$ & $0.102 \pm 0.006$ & $0.119 \pm 0.019$ \\
\hline Anthracene & $<$ d.l. & $<$ d.I. & $0.025 \pm 0.001$ & $0.024 \pm 0.008$ \\
\hline Fluoranthrene & $<$ d.I. & $0.655 \pm 0.012$ & $0.238 \pm 0.020$ & $0.230 \pm 0.024$ \\
\hline Pyrene & $<$ d.I. & $1.551 \pm 0.136$ & $0.178 \pm 0.020$ & $0.152 \pm 0.014$ \\
\hline Benzo(a)anthracene & $<$ d.l. & $0.633 \pm 0.033$ & $0.107 \pm 0.011$ & $0.080 \pm 0.009$ \\
\hline Chrysene & $35.7 \pm 0.4$ & $0.694 \pm 0.051$ & $0.108 \pm 0.005$ & $0.105 \pm 0.013$ \\
\hline Benzo(b)fluoranthrene & $<$ d.I. & $<$ d.I. & $<$ d.I. & $<$ d.I. \\
\hline Benzo(k)fluoranthrene & $<$ d.I. & $<$ d.I. & $0.057 \pm 0.004$ & $0.048 \pm 0.004$ \\
\hline Benzo(a)pyrene & $<$ d.I. & $<$ d.l. & $0.157 \pm 0.019$ & $0.147 \pm 0.011$ \\
\hline Dibenzo(a,h)anthracene & $<$ d.l. & $<$ d.I. & $0.023 \pm 0.003$ & $0.016 \pm 0.001$ \\
\hline Benzo(ghi)perylene & $27.2 \pm 2.0$ & $1.146 \pm 0.031$ & $0.103 \pm 0.012$ & $0.074 \pm 0.003$ \\
\hline Indeno(123cd)pyrene & $<$ d.I. & $<$ d.I. & $0.130 \pm 0.008$ & $0.083 \pm 0.006$ \\
\hline$\Sigma 13 \mathrm{PAHs}$ in uncontaminated soil & & & $1.363 \pm 0.102$ & $1.165 \pm 0.094$ \\
\hline$\Sigma 7$ PAHs in contaminated soil & & $5.950 \pm 0.290$ & $0.934 \pm 0.070$ & $0.824 \pm 0.083$ \\
\hline
\end{tabular}




\section{Table 2}

Collembolan densities per sample $\left(20 \mathrm{~cm}^{2}\right)$ at unpolluted and polluted plots. Significant differences betw een groups (Mann-Whitney $U$ test, $P=0.05$ ) are indicated by stars

\begin{tabular}{|c|c|c|c|c|c|c|c|c|c|c|c|}
\hline \multirow[b]{2}{*}{ Dicyrtoma fusca (Lucas, 1842) } & \multicolumn{5}{|c|}{ Control soil } & \multicolumn{5}{|c|}{ Soil over tar } & \multirow[t]{2}{*}{ Mann-Whitney } \\
\hline & 0 & 0 & 1 & 0 & 0 & 0 & 0 & 0 & 0 & 0 & \\
\hline Dicyrtomina minuta (O. Fabricius, 1783 & 0 & 0 & 0 & 0 & 0 & 0 & 1 & 0 & 0 & 0 & \\
\hline Folsomia candida (Willem, 1902) & 2 & 0 & 0 & 0 & 0 & 8 & 0 & 0 & 1 & 1 & \\
\hline Folsomia manolachei Bagnall, 1939 & 0 & 2 & 3 & 3 & 4 & 0 & 0 & 0 & 0 & 0 & * \\
\hline Heteromurus nitidus (Templeton, 1835) & 0 & 0 & 0 & 0 & 1 & 0 & 0 & 0 & 0 & 0 & \\
\hline Isotomiella minor (Schäffer, 1896) & 2 & 5 & 3 & 0 & 2 & 0 & 0 & 0 & 0 & 0 & * \\
\hline Lepidocyrtus lanuginosus (Gmelin, 178: & 10 & 2 & 0 & 3 & 8 & 0 & 0 & 0 & 0 & 0 & * \\
\hline Lepidocyrtus lignorum (Fabricius, 1781 & 7 & 1 & 0 & 2 & 0 & 0 & 0 & 0 & 0 & 0 & \\
\hline Megalothorax minimus Willem, 1900 & 17 & 4 & 2 & 3 & 10 & 0 & 0 & 0 & 0 & 0 & * \\
\hline Mesaphorura florae Simón et al., 1994 & 0 & 1 & 1 & 2 & 1 & 0 & 0 & 0 & 0 & 0 & * \\
\hline Mesaphorura hylophila Rusek, 1979 & 1 & 5 & 8 & 7 & 5 & 0 & 0 & 0 & 0 & 0 & * \\
\hline Mesaphorura macrochaeta Rusek, 197 । & 1 & 1 & 3 & 2 & 0 & 0 & 0 & 0 & 0 & 0 & * \\
\hline Micranurida sensillata (Gisin, 1953) & 0 & 0 & 0 & 0 & 1 & 0 & 0 & 0 & 0 & 0 & \\
\hline Neanura muscorum (Templeton, 1835) & 0 & 0 & 0 & 0 & 0 & 1 & 0 & 0 & 0 & 0 & \\
\hline Onychiurus jubilarius Gisin, 1957 & 0 & 1 & 0 & 0 & 0 & 0 & 0 & 0 & 0 & 0 & \\
\hline Orchesella flavescens (Bourlet, 1839) & 0 & 1 & 0 & 0 & 0 & 0 & 0 & 0 & 0 & 0 & \\
\hline Parisotoma notabilis Shäffer, 1896 & 3 & 0 & 0 & 2 & 2 & 34 & 5 & 0 & 0 & 1 & \\
\hline Proisotoma minuta (Tullberg, 1871) & 0 & 0 & 0 & 0 & 0 & 12 & 5 & 3 & 17 & 6 & * \\
\hline Pseudosinella alba (Packard, 1873) & 4 & 0 & 1 & 2 & 2 & 0 & 0 & 0 & 0 & 0 & * \\
\hline Pseudosinella decipiens Denis, 1925 & 0 & 0 & 1 & 0 & 0 & 0 & 0 & 0 & 0 & 0 & \\
\hline Sminthurides malmgreni (Tullberg, 187 । & 0 & 0 & 1 & 0 & 0 & 1 & 0 & 0 & 0 & 0 & \\
\hline Sminthurides parvulus (Krausbauer, $1 \varepsilon$ & 0 & 1 & 0 & 1 & 0 & 0 & 0 & 0 & 1 & 0 & \\
\hline Sminthurinus aureus (Lubbock, 1862) & 4 & 2 & 3 & 2 & 1 & 2 & 0 & 0 & 1 & 0 & * \\
\hline Sphaeridia pumilis (Krausbauer, 1898) & 1 & 0 & 0 & 0 & 0 & 0 & 0 & 0 & 0 & 0 & \\
\hline Stenophorura denisi (Bagnall, 1935) & 1 & 0 & 0 & 0 & 1 & 0 & 0 & 0 & 0 & 0 & \\
\hline Tomocerus minor (Lubbock, 1862) & 0 & 0 & 0 & 0 & 0 & 0 & 0 & 1 & 0 & 0 & \\
\hline Tomocerus vulgaris Tullberg, 1871) & 0 & 0 & 0 & 0 & 2 & 0 & 0 & 0 & 0 & 0 & \\
\hline Vertagopus cinereus (Nicolet, 1841) & 0 & 0 & 0 & 0 & 1 & 0 & 0 & 0 & 0 & 0 & \\
\hline Willemia buddenbrocki Hüther, 1959 & 0 & 0 & 0 & 2 & 0 & 0 & 0 & 0 & 0 & 0 & \\
\hline Willemia intermedia Mills, 1934 & 0 & 1 & 1 & 0 & 0 & 0 & 0 & 0 & 0 & 0 & \\
\hline Xenylla tullbergi Börner, 1903 & 0 & 1 & 1 & 0 & 1 & 0 & 0 & 0 & 0 & 0 & * \\
\hline Total abundance & 53 & 28 & 29 & 31 & 42 & 58 & 11 & 4 & 20 & 8 & \\
\hline Species richness & 12 & 14 & 13 & 12 & 15 & 6 & 3 & 2 & 4 & 3 & * \\
\hline Shannon Index & 3.0 & 3.5 & 3.3 & 3.4 & 3.4 & 1.7 & 1.3 & 0.8 & 0.8 & 1.1 & * \\
\hline Equitability & 0.8 & 0.9 & 0.9 & 1.0 & 0.9 & 0.7 & 0.9 & 0.8 & 0.4 & 0.7 & * \\
\hline
\end{tabular}


$\mathrm{N}=7$
$(4 \%)$
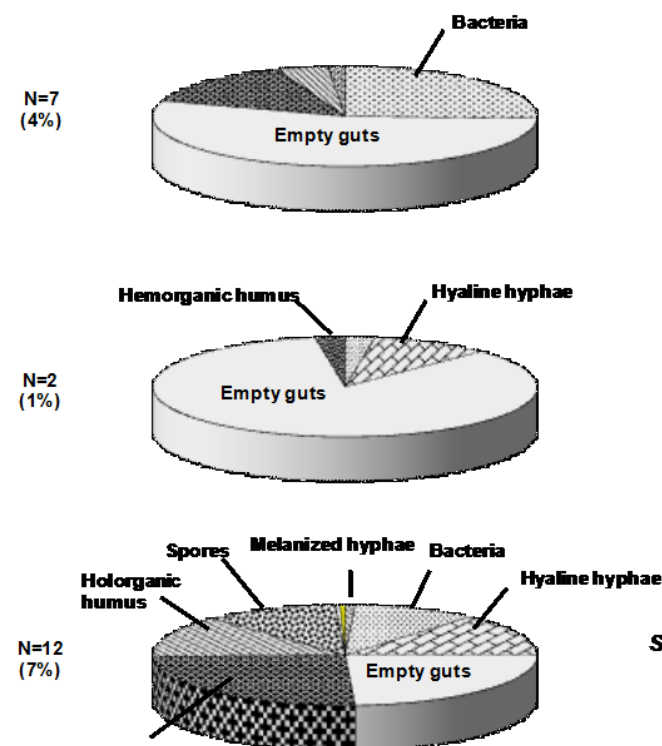

Hemorganic humus

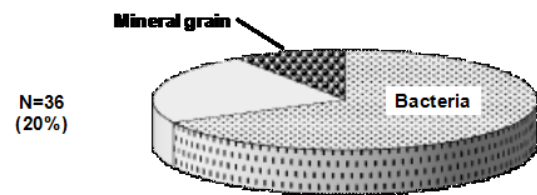

$$
\begin{aligned}
& \text { Megalothorax } \\
& \text { minimus }
\end{aligned}
$$
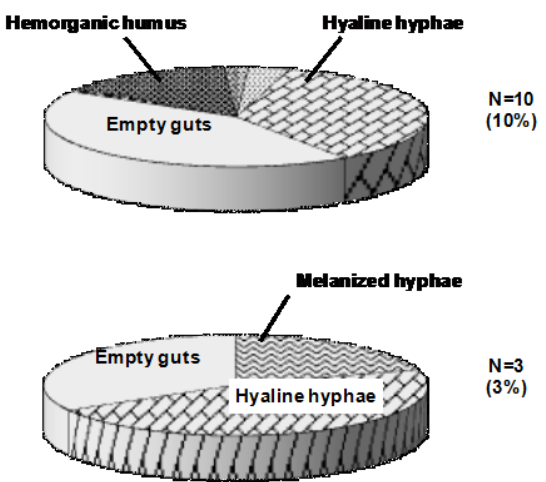

Proisotoma minuta

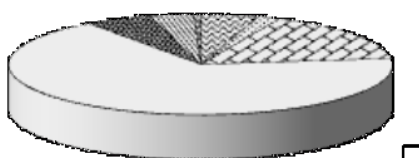

$(43 \%)$

Soil over tar

Control soil

1

$2 \quad$ Fig. 1 